\title{
Squatters' Rights and the Land Laws in Tanzania
}

\author{
By Kennedy Gastorn, Dar es Salaam*
}

\section{Land Tenure Regime in Tanzania}

Tanzania has a pluralist legal regime. Two set of laws exist governing land tenure in the country, namely statutory and customary laws. Statutory laws are those contained in the Land Act, 1999, while the framework of customary law is now under the Village Land Act, 1999. ${ }^{1}$ Two sets of tenure derived from the above structure are the 'granted right of occupancy' under the Land Act, 1999, and 'customary right of occupancy' under the Village Land Act, 1999. The two sets of tenure are combined together as a 'right of occupancy'.

The right of occupancy system traces its root back to the British colonial regime. After the defeat of Germany in the World War I, and in accordance with Article 119 of the Versailles Treaty of $1919,{ }^{3}$ Germany was forced to surrender all her foreign possessions including the colony of German East Africa. ${ }^{4}$ Tanganyika (then the larger part of German East Africa) was put under British rule as a mandate, and later a trust territory, under the supervision of the League of Nations. British rule proceeded to install a new land tenure regime that best suited its needs. In 1920 and 1922 parts of English common law were declared to be applicable in the territory. ${ }^{5}$ The concept of squatting, together with other English and common law doctrines thus entered the country. In 1923 British rule enacted

* Kennedy Gastorn, LL.B (Hons), LL.M (Dar), Dr. jur. (Bayreuth) teaches in the Department of Public Law at the Faculty of Law, University of Dar es Salaam. He is also the Associate Dean (Administration and Public Affairs) of the Faculty of Law, University of Dar es Salaam, and the Coordinator of the Tanzanian-German Centre for Postgraduate Studies in Law at the Faculty of Law University of Dar es Salaam in cooperation with the University of Bayreuth. His research interests include the areas of land law and family law. E-mail: kennedy@udsm.ac.tz

The two laws were enacted in 1999 but came into force with effect from $1^{\text {st }}$ May 2001 via Government Notices No. 485 and 486 of 2000.

On these distinctions also see Ulrike Wanitzek, Land Law and Legal Pluralism in Tanzania: Security of Customary land Tenure?, in: Jakob Rösel, et al (eds.), The Reorganisation or the End of Constitutional Liberties?, Köln 2005, pp. 188-192.

3 Signed on June $28^{\text {th }}, 1919$ at Versailles.

4 More on land laws in German East Africa see Harald Sippel, Aspects of Colonial Land Law in German East Africa: Germany East Africa Company, Crown Land Ordinance, European Plantations and Reserved Areas for Africans, in: Robert Debusmann, et al (eds.) Land Law and Land Ownership in Africa Case Studies from Colonial and contemporary Cameroon and Tanzania, Bayreuth 1996, pp. 3-38.

Order in Council 1920 and Reception Clause [Land (Law of Property and Conveyancing) Ordinance No. 2 of 1923, Cap 114] 
the Land Ordinance specifically to deal with land in the territory. ${ }^{6}$ The ordinance introduced the right of occupancy system. Essentially this is a system where the radical title on land remains in the state but people are granted rights to use and occupy land for a certain period of time under certain conditions. These rights are called 'granted rights of occupancy'.

At the enactment of the ordinance the assumption was that the indigenous people had no ownership over land. Communal or group-based ownership of land was unknown to British rule. The Land Ordinance declared all land whether occupied or unoccupied as public lands vested in His Majesty, the King of England, ${ }^{8}$ giving the state a free hand to control and alienate indigenous lands, unencumbered by any legal obligations. ${ }^{9}$ The meaning of the right of occupancy was conveniently enlarged in 1928 to include customary tenure as a deemed right of occupancy ${ }^{10}$ as an outcome of the criticisms of the Permanent Mandates Commission of the League of Nations that customary land rights of indigenous people had been left out in the Ordinance. Right of occupancy tenure still exists today. ${ }^{11}$

\section{Squatters under Common and English Law}

A squatter has been defined as one who settles on the lands of others, including public land, without any legal authority. ${ }^{12}$ Squatting is therefore an act of occupying land, not necessarily unused land, without any tenurial rights over the land. It is assumed to be the oldest mode of tenure in the world. A squatter acquires title to land through adverse possession and that is why adverse possession is also called 'squatters' rights'.

Possession is important under English law because the fact of possession of land entitles a person to retain the land against anyone in the world except someone who has

Ordinance No. 3 of 1923. More on the Land Ordiance also see Roland E. Richter, Land Law in Tanganyika since the British Military Occupation and under the British Mandate of the League of Nations, 1916-1946, in: Robert Debusmann, et al (eds.) Land Law and Land Ownership in Africa Case Studies from Colonial and contemporary Cameroon and Tanzania, Bayreuth 1996, pp 39-80; Kennedy Gastorn, The Impact of Tanzania's New Land Laws on the Customary Land Rights of Pastoralists A case Study of the Simanjiro and Bariadi Districts, Zurich 2008, pp. 27-32.

Kwame Akuffo, The Conception of Land Ownership in African Customary Law and its Implications for Development, African Journal of International and Comparative Law, 17 (2009), p. 66.

Sections 2, 3 and 4 of the Land Ordinance, Cap 113.

Issa Shivji, Not Yet Democracy: Reforming Land Tenure in Tanzania, Dar es Salaam 1998, p. 2.

Land (Amendment) Ordinance No. 7 of 1928.

11

More on conflicts between granted and deemed (customary) right of occupancy see Fauz Twaib, The Dilemma of the Customary Landholder. The Conflict between Customary and Statutory Rights of Occupancy in Tanzania, in: Robert Debusmann, et al (eds.) Land Law and Land Ownership in Africa Case Studies from Colonial and contemporary Cameroon and Tanzania, Bayreuth 1996, pp. 81-112. 
superior title. ${ }^{13}$ That is why the law puts a period of limitation upon which the holder of better title may recover or bring an action for recovery of land. ${ }^{14}$ After that period, a squatter has the right to remain in possession, having acquired a good possessory title, and old title becomes obsolete and its claim stale. ${ }^{15}$ Apart from the factual possession, which is normally demonstrated by a degree of exclusive physical control, ${ }^{16}$ a squatter must prove the requisite intention to possess the land to the exclusion of all others, including the owner with the paper title (animus possidendi). ${ }^{17}$

Following the enactment of the Land Registration Act 2002, distinction has been made between registered and unregistered land as far as adverse possession is concerned. ${ }^{18}$ In order for a squatter to obtain title to registered land, the squatter may, after being in adverse possession for ten years, apply to the land registry to be registered as owner. The land registry must then respond by sending a notice to the registered proprietor and others with registered interests in land informing them that an application has been made by the squatter. They are given 65 working days in which to object to registration of the squatter as proprietor, and generally, only if there are no objections, the squatter will be registered as having title to the land at this stage. It has been argued that these provisions are an emasculation of adverse possession in relation to registered land, signalling the end of adverse possession as a threat to the security of registered title, save in cases where the registered owner genuinely has no use for the land and does not wish to keep it. The system of registered land moves from title by registration to registration of title. ${ }^{19}$

It needs to be noted that the law of limitation was unknown to common law. ${ }^{20}$ Many rationales exist behind the law of limitation. It is in the public interest that a person who has been in undisputed possession be able to manage the land as its owner. Established and peaceable possession is therefore protected by law instead of law assisting the agitation of old claims. 'Long dormant claims have often more cruelty than justice in them, ${ }^{21}$ and those who 'go to sleep upon their claims should not be assisted by the courts in recovering their

J. G. Riddal, Land Law, London 1997, p. 468.

1412 years, according to the Limitation Act 1980, Land Registration Act 1925 and Land Registration Act 2002.

Joy Harcup, Green and Henderson: Land Law, London 1995, p. 207.

Harcup, note 15, p. 216.

18 Charles Harpum, et al., The Law of Real Property, London 2008, pp. 1411 - 1414; Lorna Fox O'Mahony, et al., Taxonomies of Squatting: Unlawful Occupation in a New Legal Order, The Modern Law Review, 71 (2008), pp. 878-911.

O'Mahony, note 18, p. 891.

20 Harpum, note 18 , p. 1409.

21

Court v. Cross (1825) 3 Bing. 329, in: Harpum, note 18, p. 1409. 
property (a duty of stewardship) ${ }^{22}$ It is also important that a civil litigation should have an end. Moreover, since possession is the basis of unregistered title, limitation facilitates the investigation of title to unregistered land. On the other hand, some people do have a strong moral stance on the immorality of squatting. It is argued that since the basis of adverse possession is wrongful possession, legitimizing it is tantamount to sanctioning theft of land, it is not logical that illegal possession can prevail over legitimate ownership (de facto $v$. de jure). ${ }^{23}$ Limitation needs to be distinguished from prescription. The latter rests on the presumption of right and not a wrongful possession which is the basis of limitation. Also prescription is primarily a common law doctrine by which a certain incorporeal rights such as easements are acquired over land of others. ${ }^{24}$

\section{Evolution of the Concept of Squatting in Tanzania}

Colonial laws and policies brought the concept of squatters to Tanzania. Likewise, colonial legal practice and colonial activities created a class of people occupying land without title to land. The majority of Africans who lived in towns during colonial time were squatters. The colonial government removed Africans from certain sections of towns and placed strict conditions on them for remaining in town. ${ }^{25}$ Even some richer Africans who could afford to acquire, and build on, urban plots, preferred to build outside the towns where they were free of the tough and peculiar township building and health regulations under which Africans were allowed to settle in towns. ${ }^{26}$ In British colonial days it was also the practice that upon the extension of city or town boundaries, urban lands ceased to be subject to native law and custom upon payment of compensation to the former holders who were affected by the order. Those who remained within the urban boundaries came to be called squatters. ${ }^{27}$ Interestingly, the law of limitation was not applicable to the government because squatters could be evicted at the will of the government at any time. As it was held in Muhena Bin Said v. Registrar of Titles ${ }^{28}$, the doctrine of long possession, which is the basis of adverse possession, was a creature alien to native law. Therefore squatters in the Tanzanian context differed in certain aspects from his or her counterpart under the English law.

Squatters were also created through land alienation. Colonial government acquired huge chunks of fertile land occupied by indigenous people and caused them to search for

Streatford J. in R B Policies at Lloyd's v. Butler [1950] 1 KB 76. Also see E. H. Burn, Land Law: Cases and Materials, London 1986, p. 162.

23

24

25

26

27

28

O'Mahony, note 18, p. 982.

Harpum, note 18, pp. 1410-1411.

More on colonial urban policy in Tanzania see Andrew Burton, African Underclass Urbanisation, Crime and Colonial Order in Dar es Salaam, Dar es Salaam 2005.

East Africa Royal Commission 1953-1955 Report, Cmd 9475, Chapter 19, paras 60-64.

Roden William James, Land Tenure and Policy in Tanzania, Dar es Salaam 1971, p. 100.

(1948) 16 EACA 399. 
alternative land for grazing and cultivation. The absence of paper title reduced customary landholders to no better than squatters. It has to be remembered that the 1923 Land Ordinance disowned indigenous people of their land by declaring all land as public land under the control and subject to the disposition of the Governor, and no title to the occupation and use of any such lands shall be valid without the consent of the Governor. Even the amendment of the Land Ordinance which recognised customary title as deemed right of occupancy was only declaratory, ${ }^{29}$ which in itself could not safeguard the customary rights of the indigenous people. ${ }^{30}$ Occupation of land under customary law was legally construed by courts as permissive in the nature of licences. ${ }^{31}$ James argues, nevertheless, that technically Africans occupying public lands were in lawful occupation of such lands under deemed rights of occupancy, provided they occupy and use such lands in accordance with African law and customs. ${ }^{32}$

An artificial shortage of land by dispossessing and denying natives their land rights, not only made them squatters on public land but was also used deliberately to ensure the availability of labour to the colonial plantations. The Land Ordinance provided a legal framework for plantation agriculture in Tanzania. ${ }^{33}$ Without land, people had nothing but their labour to be sold for a wage in the plantations. This also happened in many other jurisdictions. In Kenya, for instance, by the alienation of land of indigenous people, inhabitants were turned into squatters. Yet the colonial government proceeded to prohibit natives from settling on any land held by Europeans unless bona fide employed by the owner. The reason being that 'the Europeans settlers who have invested their fortunes in the country at the invitation of the British government cannot be blamed for demanding native labour. Put in the same situation, the twelve apostles would not have acted otherwise'. ${ }^{34}$ Therefore the demand for labour could only be satisfied through squatterdom rather than wage labour.

Tanganyika independence in 1961 did not greatly change the position of customary landholders. Several colonial practices survived independence, and in land laws the big change was the substitution of the word "Governor" for "President" wherever it appeared. ${ }^{35}$ It was for instance still assumed that native law and customs were only applicable in rural areas but not in urban centres where land could not be acquired other than by grants of

Land (Amendment) Ordinance No. 7 of 1928.

30

Shivji, note 9 , p. 3.

Gamaliel Mgongo Fimbo, Land Law Reforms in Tanzania, Dar es Salaam 2004, p. 4. Also see Muhena Bin Said v. Registrar of Titles (1948) 16 EACA 399; Mtoro Bin Mwamba v. A.G. (1953) TLR 327.

Fimbo, note 31, p. 3.

Thabita Kanogo, Squatters and the Roots of Mau Mau 1905 - 63, Nairobi 1987, p. 35. More on squatters in Kenya also see Karuti Kanyinga, Re-Distribution from Above The Politics of Land Rights and Squatting in Coastal Kenya, Uppsala 2000. 
rights of occupancy. Therefore when an area is given urban status customary law ceases to apply, and the former owner who has become a squatter must apply for a granted right of occupancy. ${ }^{36}$ In general the Land Ordinance was not entirely unambiguous on the legality or illegality of Africans' rights to town lands. ${ }^{37}$ Other policies of independent government contributed much to the uncontrolled growth of unplanned settlements within and at the fringes of urban centres. This was partly due to the inherited colonial planning laws that could not easily be availed of by the mass of the population because of their over-ambitiously legalistic nature, ${ }^{38}$ lack of sufficient surveyed plots, bureaucracy in land administration procedures, the unregulated land market, population increases in urban centres and the uncontrolled alteration of town master plans. ${ }^{39}$ The independent government was indeed vigilant in preventing squatting activities, only it had no capacity to counter the magnitude of the problem. For instance, nearly two weeks after independence the government warned squatters not to continue erecting houses on public land without title because it was determined not to pay them compensation if the government decided to clear the land for public purposes. ${ }^{40}$ It even warned squatters that their presence hindered several national development projects, citing Tanga region as an example, which had missed two opportunities for industrial establishment due to squatting. ${ }^{41}$ Informal landholding cum squatting continued to exist. In 2002 the Ministry of Lands made it clear that squatting accompanied by occupation constituted $18 \%$ of the actions by which people accessed land in urban areas in Tanzania. ${ }^{42}$ And in 2003/4 it was estimated that $80 \%$ of all residential houses in Dar es Salaam were in the unplanned settlements. ${ }^{43}$ In 2007, the Minister for Lands clarified that over $70 \%$ of urban Tanzanians live in non-surveyed areas, $25 \%$ of the population in the country lived in surveyed areas and the housing deficit in urban areas alone was estimated

James, note 27, p. 101.

Town and Country Planning Ordinance, 1956. See Ibrahim Hamisi Juma, et. al., Tanzania: PeriUrban Land Insecurity in Dar es Salaam, in: Gordon Woodman, et al (eds.), Local Land Law and Globalization A Comparative Study of Peri-Urban Areas in Benin, Ghana and Tanzania, Muenster 2004, pp. 249-255.

James, note 27, pp. 100-105; Twaib, note 11, p. 101. For instance in the Guardian (Tanzania), December 20, 2007, p. 1, the Minister for Lands confessed as being fed up with avalanche of written proposals from district officials seeking to alter the status of open spaces in the master plans.

Tanganyika Standard, December 28, 1961, p. 3; Mwafrika, June 19, 1963, p.1.

Tanganyika Standard, May 25, 1963, p.1.

Salome Sijaona, Land Issues and the National Development Strategy: The Tanzania Experience, Dar es Salaam 2002, p.7. 2005. 
at 1.2 million units. ${ }^{44}$ To this end, the usage of term 'squatters' in its true sense seemed unwelcome and instead terms like 'unplanned settlements' and 'informal landholders' were preferred.

In rural areas, the land tenure confusion caused by the rural development approach of the villagisation programme in the 1970s left millions of customary landholders uncertain of their tenure. ${ }^{45}$ Villagisation was a compulsory scheme of resettling people in villages so that they could produce on a communal or cooperative basis. The main purpose of the villagisation programme was to speed up rural development through agriculture. ${ }^{46}$ The programme hardly took into account contradictions between the existing land tenure system and the new tenure system to be installed in the villages. It created land tenure confusion and, as has been argued, the resulting mass relocation of people into new villages opened up possibilities of alienation of village land on a scale greater than prevalent even during colonial times. ${ }^{47}$ Villagers became informal landholders because their title to land was uncertain. In the villages in question land was not acquired in accordance with either customary law or statutory tenure. 48

It needs to be noted that the government had earlier on, before the villagisation programme, already embarked on similar resettlement schemes near cities as a way of fighting unemployment in towns. For instance in 1962, a 3,000 acre resettlement area at Tumbi (Kibaha), 24 miles from the city centre of Dar es Salaam, was created to provide a farming livelihood for 200 unemployed persons. The exercise was carried out on a voluntary basis. ${ }^{49}$ The government had even threatened that if people continued to stay in towns without moving to villages to farm, ${ }^{50}$ it would have no option but to give foreigners land so that they could produce for the benefit of the nation. ${ }^{51}$

Hon. John P. Magufuli, M.P. See Daily News (Tanzania), December 20, 2007, p.1; The Guardian (Tanzania), December 20, 2007, p.1.

United Republic of Tanzania, Report of the Presidential Commission of Inquiry into Land Matters, Vol. I, Land Policy and Land Tenure Structure, Uppsala 1994, chapter IV, para 81. On villagisation and land tenure also see Wanitzek, note 2, p. 180.

Julius Kambarage Nyerere, Freedom and Unity: Uhuru na Umoja, Dar es Salaam 1967, pp. 176187, Julius Kambarage Nyerere, Freedom and Socialism: Uhuru na Ujamaa, Dar es Salaam 1974, pp. 337-366.

Shivji, note 9, p. 12.

S. 15 Village Land Act has clarified this point that the tenure was customary.

Tanganyika Standard, August 23, 1962, p. 4.Also see The Nationalist August 5, 1964, p. 2. Tanganyika Standard, May 10, 1963, p. 1. 


\section{Courts Articulation of the Concept of Squatters in Tanzania}

British colonial land tenure structures survived independence. The system continued to apply with minor modifications to suit the needs of the new government. Therefore the concept of squatters remained although not applied as before. Since the concept was used politically against the interests of the natives during colonial days, and therefore resisted by natives, the independent courts had a different approach to it, particularly in relation to African rights on town lands.

In Metthuselah Paul Nyagwaswa v. Christopher Mbote Nyirabu ${ }^{52}$, one issue was whether, once an urban area is declared a planning area, existing customary rights become extinct. As noted above, the practice during colonial times was that upon the extension of city or town boundaries, urban lands ceased to be subject to native law and custom upon payment of compensation to the former holders affected by the order. Those who remained within the urban boundaries came to be called squatters. The court resolutely held that:

"...the law in Tanzania on land and land tenure is still developing and certain areas are unclear and would have to await the necessary legislation. At any rate I am not prepared, on the rather inconclusive and tenuous arguments advanced in this appeal, to hold that the right of a holder of a right of occupancy by virtue of native law and custom is extinguished and he thereby becomes a squatter on an area being declared a planning area".

Since the law was still developing, the court avoided giving a clear verdict on the issue. This might imply that given other conditions, such as compensation being paid, a landholder may be a squatter. Later, in Mwalimu Omari and Another v. Omari A. Bilali, ${ }^{53}$ the court considered the assumptions on squatters in view of the status of customary tenure holders in urban or town areas. The court held that:

"Title under customary law and a granted right of occupancy in an area declared township or minor settlement cannot co-exist. Title to urban land depends on grant. Once an area is declared an urban planning area and land is surveyed and plot demarcated whoever occupies land under customary law has to be quick to apply for right of occupancy. If such person sleeps on such right and the plot is given to another, he becomes a squatter in law and would have to move away; he strictly would not be entitled to anything".

The court had the advantage of the judgment in the Nyangaswa case above. The court clarified the decision in Nyangaswa's case as follows:

"What Mustafa J.A. said in Nyangaswa's case is that after an area is declared urban planning area, a squatter or a person holding title under customary law continues to enjoy some rights, e.g. compensation but this was not superior to that of a holder of right of occupancy. Squatters have a right of facing authorities for fast registration if they comply with set down rules. If they do not do so and someone is granted the plot, they can only be compensated for unexhausted improvement". 
In this regard, a squatter is as good as a person holding customary tenure in a planning area. Also a customary landholder, once an area is declared a planning area, becomes a squatter with two rights, namely right for compensation for unexhausted improvements, and right to be considered first for new title upon application for the same.

In Rashid Makwamba \& 1016 others v. Kilombero Sugar Co. $\mathrm{Ltd}^{54}{ }^{54}$ villagers settled and occupied a piece of land for a number of years. It was later discovered that the land in question belonged to one legal person under title, although it was unused land. Villagers were sued for trespassing on the land in question. The villagers disputed the claim as they had occupied the land for a long period of time. The court held against the villagers that they were squatters having intruded and trespassed on the land, and had no rights whatsoever but to vacate the area. At this juncture, a squatter as a person holding land without any tenurial rights over the land needs to be distinguished from a person holding land in a surveyed or planning area by virtue of being the former occupier of the land under customary law. A clear distinction between the two is put by Twaib. ${ }^{55}$ According to Twaib, a person on land without tenurial rights is a squatter per se, not entitled to compensation and his or her occupation is merely permissive, he or she therefore having no right to continue staying on a piece of land after it has been allocated to someone else. ${ }^{56}$ But for the previous holder in customary law, his or her rights remain legally recognized until they are lawfully acquired. $^{57}$

\section{National Land Policy and Squatters}

Tanzania put in place, for the first time, the National Land Policy in 1995 as a policy framework upon which new land laws should be modeled, and all persons exercising powers under, applying or interpreting the laws should have regard to. The National Land Policy provides that;

(a) The existing [squatter] areas will not be cleared, but will be upgraded and provided with facilities for adequate sanitation and other services except for unplanned housing in hazardous areas. $^{58}$

(b) Residents in unplanned urban settlements shall have their rights recorded and maintained by the relevant land allocating authority and that record will be registered. 59

For example see Rashid Makwamba \& 1016 others v. Kilombero Sugar Co. Ltd, Land Case No. 15 of 2003, High Court of Tanzania (Land Division) at Dar es Salaam (unreported).

Twaib, note 11, p. 98.

Pancras Alexander v. R (1981) TLR 92.

Suzan Kakubukubu v. Walwa Joseph Kasubi, High Court of Tanzania at Mwanza, Civil Case No. 13 of 1987 (unreported). 
(c) The land rights of peri-urban dwellers will be fully recognized and rights of occupancy issued. $^{60}$

Also the Human Settlements Policy of 2000 issued by the Ministry of Lands, Housing and Urban Development ${ }^{61}$ calls for the need to recognize unplanned settlements and provides strategies for curbing development and regularisation of the same.

The implications of the above policies may be seen from the fact that the squatter or unplanned settlements phenomena in Tanzania revolve also on the role of the government as a provider of basic social services and the people (squatters) as recipients of the services. This has influenced the juridical and policy approaches to the question, as seen above, and the approaches have defied the English myth that 'squatters are parasitic deviants who steal people's houses and constitute a threat to everything decent in society'. ${ }^{62}$ The government is determined to grant squatters in unplanned settlements immediate provision of services such as power and water, and is proceeding to take early steps to check the sprawl of unplanned settlements and not to wait until when it is too late to demolish structures. It has recognized that although squatter areas are unplanned, they nevertheless represent assets both in social and financial terms. Responses seemed to require a balancing of two questions: fault on the part of both the squatter and the government (as virtual land owner) and the hardship likely to be occasioned upon each party in the event of alternative legal outcomes. Four factors may be considered in determining the appropriate legal responses to squatter tenurial land rights in Tanzania: ${ }^{63}$ the identity of squatters; the type of property in question; the squatter's motives; and the conduct of the land owner.

In principle, all squatters in Tanzania are people entitled to any vacant public land. All land belongs to the nation. It is vested in the President as a trustee for the benefit of the citizens. ${ }^{64}$ In absence of freehold ownership, land is mainly occupied on condition that it is developed. This means that citizens can not only move and reside wherever they want but also occupy land anywhere provided they use it. ${ }^{65}$ That is why, especially after independence, the majority moved to towns in search of a better life. ${ }^{66}$ This political and legal environment regarding citizens' rights to occupy land encourages people to make good use of all unused land whether in town, peri-urban or rural areas. What makes them squatters is the absence of formal title to land, mainly by non-compliance with the acquisition procedures, planning laws, and uncertainty over the application of customary tenure in urban

60

61

62

63

64

65

66

National Land Policy, para 6.3.1. (iii)

Now the Ministry of Lands and Human Settlements Development.

O'Mahony, note 18 , p. 883

Based on the current factors considered significant in the UK, see O'Mahony, note 18, p. 882.

National Land Policy, para 4.1.1(i); S. 3(1) Land Act.

Nyerere, note 46, pp. 53-58.

In colonial time, African were removed or prevented from living in towns. See East Africa Royal Commission 1953-1955 Report, Cmd 9475, Chapter 19, para 60-64; Burton, note 25. 
areas. The type of property is generally unused public land. As to the motives of squatters, it ranges from lack of alternative, deliberate acquisition of title to simply mistaking urban boundaries and those of neighbouring villages. Village lands are often engulfed by town boundaries or declared planning areas without sufficient notice to the landholders. ${ }^{67}$ Villagers, who later become squatters in law, continue holding their land for they have not been given alternative land or their rights are yet to be lawfully extinguished. They are good faith squatters for they bear no fault in relation to their land occupation. ${ }^{68}$ The conduct of the government here leaves a lot to be desired. Inability of land delivery system and poor planning laws promote the sprawl of unplanned settlements in urban and peri-urban areas. In many cases, the government has deliberately or otherwise failed the duty of stewardship bestowed upon it as the virtual land owner (trustee).

\section{The Question of Squatters in Law Drafting Stages}

The issue of different classes of squatters with different treatment in the eyes of law came out significantly during the drafting process of the new land laws. As noted above, the Ministry of Lands acknowledged that 'squatting accompanied by occupation' constitutes $18 \%$ of the ways in which people access land in urban areas in Tanzania. ${ }^{69}$ Again the policy is interested in protecting squatters or informal landholders. It was noted with concern that unauthorised market transactions for land had existed for several years and must therefore be recognised and not be ignored or the 'fiction' maintained that all people who have 'paid' for land have no rights and are only squatters, liable to be dispossessed without compensation at any time.

It was then suggested, among other things, that the term 'squatter' be defined and also the different classes of squatters be included in the land laws.

\section{Intervention of Land Laws to the Question of Squatters}

Land law provides neither definition nor a classification of squatters. It however contains several schemes to enable squatters cum informal landholders to validate or formalize their tenure. ${ }^{72}$ This includes schemes for the 'validation' and 'regularisation' of interests in land.

67

68

69

70

71

72

National Land Policy, para 6.2.0.

Under English law, unlike in USA, there is no distinction between good faith trespassers and bad faith trespassers.

Sijaona, note 42, p. 7.

Patrick McAuslan, Clause-By-Clause Commentary, A Draft Bill, Dar es Salaam 1996, para 10.2.

McAuslan, note 70, p.118 (Discussion Group III on Dispute Settlements\& Miscellaneous Part XIII-XIV).

Part VII Land Act. 


\section{(a) Validation of Interests in Land}

The validation scheme applies to disposition of a right or interest in land held under customary or informal tenure irrespective of where the land is located. ${ }^{73}$ Disposition is broadly defined to include sale, mortgage, transfer, grant, partition, exchange, lease, assignment, surrender, disclaimer, creation of an easement, or a usufructuary right. ${ }^{74}$ Under the validation scheme a disposition must have been drawn up between parties who should have but did not obtain a grant of approval from the relevant authority, such as the commissioner for lands, or have applied for a grant of approval and having been refused nonetheless proceeded to carry out that disposition. ${ }^{75}$ An occupier of land through this disposition automatically has two rights. First, his or her occupation is deemed lawful for a period of six years from 2001 (a date of commencement of the Land Act, 1999) or any longer period as the Minister for Lands may determine. Secondly, he or she may apply to the commissioner for lands for a certificate of validation of that occupation. ${ }^{76}$ With the certificate of validation, the occupier, if the disposition in question was for transfer of right of occupancy, is entitled to apply and obtain a right of occupancy for a period of not less than thirty-three years. ${ }^{77}$

Non-application for certificate of validation within the prescribed time would render such interest occupied as a deemed licence, valid and irrevocable until the end of the given six years or more as the case may be. ${ }^{78}$ A licence holder within this period of time may apply for a right of occupancy in accordance with ordinary procedures under the Land Act, 1999. ${ }^{79}$ If refused, he or she will be entitled to compensation for the value of the unexhausted improvements on land. ${ }^{80}$ In the premises, it is clear that validation of unauthorised land market transactions that were done under the previous legal regime was a deliberate attempt to redress the symptoms that resulted, as Mutakyamilwa puts it, 'from a malfunctioning government land delivery system partly because of corruption coupled with budget

73

74

75

76

77

78

79

80

S. 53 Land Act.

S. 2 Land Act.

S. 53(1) (a) and (b) Land Act.

S. 53(2) Land Act. An application for a certificate of validation is done on a prescribed form, accompanied by the prescribed fee, and it must be signed by the applicant or his duly appointed representative or agent, and must contain any other information as may be prescribed or which commissioner for lands may require.

S. 53(5) Land Act.

S. 54(1) Land Act

SS. 24 to 52 Land Act.

S. 54(3) Land Act. Unexhausted improvements include anything or qualities permanently attached to the land directly resulting from the expenditure of capital or labour by an occupier or any person acting on his behalf and increasing the productivity capacity, the utility, or the sustainability of its environmental quality and include trees, standing crops and growing produce whether of an agricultural or horticultural nature. See S. 2 Land Act. 
limitations that impacted on the capacity to adequately deliver land in urban areas, periurban areas and areas with high agricultural potential'. 81

The government was also unable to control illegal sub-division, change of use and occupation of the illegally sold and purchased land in the market. Informal land transactions were also fuelled by the fact that government land policy did not facilitate the operation of property markets by allowing people to sell undeveloped land to developers. ${ }^{82}$ Bare lands were legally considered as of no value but practically marketable. The National Land Policy now recognizes that land has a value. ${ }^{83}$ This is a remarkable shift from the hypocrisy of the past, to use the words of Twaib, which had even refused to recognize the reality of the land market that has existed for a long time in the country. ${ }^{84}$ To this end, the new land laws through the validation process seek to address this reality by attempting to 'legalise' what was 'illegal' under the hitherto legal regime, ostensibly to avail tenure security to 'squatters cum informal landholders' as victims of previous land delivery system failure. Indeed, this is a compromise package by the government in its limited capacity to deliver land to citizens and its failure to control the occupation and development of land obtained outside of the established legal framework. ${ }^{85}$ The difference between people who obtain land from outside the established legal framework and squatters is hard to find.

\section{(b) Regularization of Interests in Land}

Regularisation is a scheme of determining the interests in land which exist in the large unauthorised settlements in and around the urban areas by recording them and allocating tenure security to the occupiers and users of land in those areas. The Land Act categorically provides that the purpose of the regularisation scheme is to facilitate the recording, adjudication, classification and registration of the occupation and use of land by informal landholders in a given area. ${ }^{86}$ The Tanzanian regularisation scheme is designed to apply within the boundaries of any urban authority or any land in a peri-urban area whether that land is within the boundaries of a village or not. ${ }^{87}$ Only the Minister for Lands, suo motto or at the request of an urban authority or village council, has the power to determine and declare a scheme of regularisation over a particular area. Before declaration, the minister is required first to direct the commissioner for lands to prepare or cause a draft of the scheme to be

Fidelis Mutakyamilwa, Harmonisation of Land Markets Development with Tenure Security under the Land Act, 1999 and the Village Land Act, 1999, Dar es Salaam 2005, pp. 174-5.

82

83

National Land Policy, para 4.2.17.

National Land Policy, para 4.1.1 (b).

Fauz Twaib, Land Law and the Growth of human Settlement in Tanzania A Research Report, Recht in Afrika (2000), p. 84.

Mutakyamilwa, note 81, p. 176.

S. 57(1) Land Act.

S. 56 Land Act. 
prepared. ${ }^{88}$ The minister is also responsible for the implementation of the scheme but he may delegate the responsibility to the commissioner or village council depending on where the scheme takes place. ${ }^{89}$ According to section 57 of the Land Act ${ }^{90}$, the criteria to be taken into account in determining whether to declare a scheme of regularisation in any area are the following:

(a) whether the area is used substantially for habitation in dwellings of their own construction or dwelling places adapted from buildings abandoned by their former occupiers by persons holding at the will or sufferance of a person having title to the land or as a trespassers;

(b) whether a substantial number of persons living in the area appear to have no apparent lawful title to their use and occupation of land notwithstanding that they have paid for or are paying for the land they are occupying and are managing the land in accordance with rules generally recognised within the area;

(c) whether the land, although part of an urban local authority is occupied under customary land law, where that customary land law is the law of one group of people living in the area;

(d) whether the area is a substantially built-up area;

(e) whether the area has been or is likely to be declared to be a planning area under the Town and Country Planning Act;

(f) whether the area has a substantial number of persons who have lived there for a substantial period of time so that the area is a well established, and settled area from a social point of view;

(g) whether there is evidence that despite the lack of any security of tenure for the persons living in the area, a considerable number of such persons appear to be investing in their houses and businesses and attempting to improve the area through their own initiatives;

(h) whether a substantial number of people and community-based organisations within the area indicate that they wish to participate in a scheme of regularisation; and

(i) such other criteria as may be prescribed or which the Minister considers relevant.

The Land Act provides also that a scheme of regularisation may contain all or any of the following matters: ${ }^{91}$

(a) arrangements for the survey, adjudication and recording of the interests in land claimed by those persons occupying land in the regularisation area;

(b) arrangements for the readjustment of the boundaries of plots of land;

(c) arrangements, within the framework of the rights in land provided for under paragraphs (a) and (b) for the better planning and layout of the land, including the pooling, sharing and redistribution of rights in land;

(d) arrangements for the involvement of the local authorities having jurisdiction in the regularisation area in the implementation of the scheme; 
(e) arrangements for the involvement of the people whose land is the subject of the scheme of regularisation in the implementation of the scheme;

(f) arrangements for the assessment and payment of any compensation that may become payable as a result of the implementation of the scheme; and

(g) a budget for the scheme.

At the end of the regularization scheme residents in the area will be issued with rights of occupancy as a formal title to land (tenure). To this end, clearly the idea of regularization is in harmony with the spirit of the National Land Policy of accommodating informal landholders who are on land without title. Long-standing use of land is the most important thing in this regard. Despite the fact that there are few models of legal regimes for the operation of the regularisation process within Africa, land regularisation is mandated as an appropriate policy for dealing with the land and housing problems of the urban poor by the Habitat Agenda. ${ }^{92}$ No wonder Fimbo argues that the Tanzanian scheme of regularization is about squatter upgrading intended to protect members of the petty bourgeoisie ${ }^{93}$ who have bought vast tracts of land in suburbs and villages on the fringes of urban areas such as the Mlalakuwa, Makongo, Msewe and Kimara areas of Dar es Salaam City. ${ }^{94}$

\section{The Future of Squatters' Land Rights in Tanzania}

Squatters have remedial measures (via validation and regularisation of their interests in land) to change their status by formalizing their land tenure. In future it is important that people should avoid living in insecurity by following the required procedures of acquiring and holding land.

This presupposes that the government as a land service provider will have done its part. In this regard, the government too has a key role to play in avoiding the future growth of squatters' areas. As the National Land Policy provides, ${ }^{95}$ the government should:

(a) timely plan all the potential areas for urban development in the periphery of all towns,

(b) design special areas for low income housing with simplified building regulations and affordable level of services,

Adopted at the UN HABITAT Summit at Istanbul City in 1996. See Patrick McAuslan, Comments About Angolan Land Law Draft, 2003, p. 9. Also available at http://www.dwangola.org/ dwWEB/english/pdf/cedoc_pdf/Angola\%20Land\%20Law\%20-\%20of\%20the\%20Republic\%20 of\%20Angola\%20Patrick\%20Mc.pdf.

Analytical term describing a social stratum in possession of state power in a post-colonial state; it includes the national leadership, intellectuals, higher civil servants, higher military and police officers as well as prosperous traders. It is allied to the international bourgeoisie but subordinate to it. See Fimbo, note 31, p. xii. 
(c) make land services readily available, and

(d) upgrade all existing squatter areas and provide them with tenure security and basic social services.

\section{Conclusion}

Because of its nature, it cannot constitute good public policy to simply protect squatters. As held in Mwalimu Omari and Another v. Omari A. Bilali ${ }^{96}$ squatters in the eyes of law cannot equate themselves to any person holding a title under right of occupancy even where the squatter occupies land under customary law. On the other hand, due to the uncontrolled growth of unplanned settlements in the country, squatting has, albeit de facto, been accepted as a way of accessing land in urban and peri-urban areas. Nearly all houses in urban areas, including those of decision makers, lie in unplanned areas. Hence it is neither practical nor just to call all these people on land without title squatters, let alone attempt to remove these hundreds of thousands of squatters from within or the fringes of cities.

That is why, arguably, the new land laws refrain from not only defining but also mentioning the word 'squatters'. 97 This is despite the fact that squatting accompanied by occupation constitutes $18 \%$ of the ways in which people access land in urban areas in Tanzania. ${ }^{98}$ The land laws significantly accommodate squatters by recognizing that they are there to stay and wish to make positive contribution to their country, towns, society and themselves. Accordingly, it supports them by giving them tenure security through schemes of validation and regularisation of interests in land. This is likely to encourage them to invest in their lands as developers, not squatters, and to remain good citizens. They need to be tolerated for want of a practical alternative.

Squatters protected by land law are those who have settled on public land other than reserved and hazardous land which has no existing private right or protected interest. This includes those who have acquired land through unauthorized property market transactions. The spirit of the land laws is to recognize, clarify and secure in law any form of informal tenure including the existing long standing use and occupation of land for people who are without apparent lawful title to their use or occupation of land. ${ }^{99}$ This is even more justified in a country like Tanzania where land is public property belonging to all citizens with the President as a trustee, where only $25 \%$ live on surveyed land, the urban housing deficit stands at 1.2 million units and over $70 \%$ of urban dwellers live in unsurveyed areas. ${ }^{100}$

Mwalimu Omari and Another v. Omari A. Bilali (1990) TLR 9.

Even trespassers are seldom mentioned in sections 57(2)(a) and 151(3) Land Act as well as 24(5) and 57(3)(b) Village Land Act.

Sijaona, note 31 , p. 7.

99

S. 3(1) (b) Land Act.

Hon. John P. Magufuli, M.P. Daily News (Tanzania), December 20, 2007, p.1; The Guardian (Tanzania), December 20, 2007, p.1. 
The challenge then to land administrators is how to swiftly regularize existing unplanned areas; plan ahead of development; make land services like plot surveying and building permits less costly, less bureaucratic and readily available; take early steps to check the further sprawl of unplanned settlements; and not to wait until it is too late, which would compel them to resort to squatter upgrading schemes which are relatively expensive and difficult to manage. 